\section{Comparative Performance of Different Plastic Films for Soil Solarization and Weed Suppression}

\author{
Harsimran K. Gill ${ }^{1,3}$, Robert McSorley ${ }^{1}$, and Danielle D. Treadwell ${ }^{2}$
}

ADDITIONAL INDEX WORDs. Cyperus rotundus, durability, nutsedges, plastic mulch

SUMMARY. Soil solarization is an important practice for small-acreage farmers and home gardeners and is used commercially in areas with high solar radiation and air temperature during the summer. In this technique, clear plastic films are used to increase soil temperature to manage soil-borne plant pests such as insects, diseases, nematodes, fungi, and weeds. Several different kinds of plastic films were evaluated in 2007 and 2008 for durability, weather tolerance, and weed suppression. Treatments were arranged in a randomized complete block design with five replications. In 2007, treatments were four clear plastic films including: ISO, VeriPack, Poly Pak, Bromostop ${ }^{\circledR}$, and a white plastic control. In 2008, treatments were Polydak $^{\circledR}$, Poly Pak, Bromostop ${ }^{\circledR}$, and white plastic. Films were evaluated for weed suppression based on the population density of weeds that emerged through breaks in the plastic, for durability in terms of number and size of breaks in the films, and for the total exposed soil area resulting from breaks. Purple nutsedge (Cyperus rotundus) was the major weed problem throughout both years. In both years, total exposed area was greater with white plastic and Bromostop ${ }^{\circledR}\left(81.5 \mathrm{ft}^{2} /\right.$ bed) compared with other plastic films $\left(<21.5 \mathrm{ft}^{2} /\right.$ bed $)$. Due to their durability, Poly Pak, ISO, and VeriPack suppressed nutsedge more than Bromostop and white plastic. Although a number of very small $(<0.75$ inch long) breaks were observed in Polydak ${ }^{\circledR}$ plastic film, they never increased in size, and this plastic film remained intact throughout the experiment and provided excellent weed control.

S oil solarization, also referred to as solar heating or solar pasteurization, is accomplished by passive heating of moist soil covered with transparent plastic film for more than 6 weeks (McGovern and McSorley, 1997). Solarization is a useful nonchemical technique for controlling weeds, nematodes, and several soil-borne diseases (Katan, 1987; McGovern and McSorley, 1997; Stapleton, 2000).

This paper is submitted in partial fulfillment of the requirements for the $\mathrm{PhD}$ of the senior author.

This research was supported in part by USDACSREES Methyl Bromide Transitions Program grant no. 2006-51102-03566 entitled "Short-term methyl bromide alternatives for the Florida floriculture industry," and by USDA-ARS Specific Cooperative Agreement no. 58-6618-6-207 entitled "Management of root-knot nematodes and other soilborne pests in floriculture production systems."

We thank Marc Branham, Susan Webb, and Gaurav Goyal of University of Florida for reviewing and improving an earlier version of manuscript. We also thank Heidi HansPetersen and Namgay Om for assistance in the field, and Buck Nelson and the staff of PSREU for management of field plots.

Mention of any trade names or products does not imply endorsement or recommendation by the University of Florida or the USDA.

${ }^{1}$ Department of Entomology and Nematology, Uni versity of Florida, P.O. Box 110620, Gainesville, FL 32611-0620

${ }^{2}$ Department of Horticultural Sciences, University of Florida, Gainesville, FL 32611-0690

${ }^{3}$ Corresponding author. E-mail: simgill@ufl.edu.
The increased temperature $\left(45-55^{\circ} \mathrm{C}\right)$ at a 5 -cm soil depth under clear plastic films caused mortality of a variety of plant pathogens (Katan, 1981). Solarization has been shown to be most effective in regions that are cloudless and have hot weather (Heald and Robinson, 1987; Katan, 1981; Stapleton and DeVay, 1983). This technique has also been applied in regions with humid climates, such as Florida (Chase, 2007; Chellemi et al., 1993, 1997; McGovern et al., 2004; McSorley and Parrado, 1986), except when a prolonged period of rain occurred (Wang et al., 2006). Solarization was found to be a costeffective (Chellemi et al., 1997; Katan, 1981) and low-risk management practice for small farmers and has the potential to increase crop yield (Culman et al., 2006).
Solarization has been helpful in managing a variety of pests and diseases and, as a result, in increasing crop yield. Solarization decreased population levels of different species of nematodes (Chellemi et al., 1997; McGovern et al., 2002; McGovern and McSorley, 1997; Stapleton and Heald, 1991). In Italy, solarization was used to manage lettuce drop caused by the fungus Sclerotinia minor and reduced the disease from $51 \%$ to $84 \%$, leading to $37 \%$ to $86 \%$ increases in production of lettuce (Lactuca sativa) (Scannavini et al., 1993). In Florida, a combination of solarization followed by fumigation under virtually impermeable film (VIF) reduced the survival of the fungus Fusarium oxysporum f. sp. lycopersici (Chellemi and Mirusso, 2006).

Solarization is also very effective in controlling weeds (Chase et al., 1998; Daelemans, 1989; Elmore et al., 1997; Horowitz et al., 1983). In Turkey, solarization in combination with other treatments provided effective control of different annual weeds such as annual bluegrass (Poa annua), common purslane (Portulaca oleracea), redroot pigweed (Amaranthus retroflexus), and barnyardgrass (Echinochloa crusgalli), but not horseweed (Conyza canadensis) (Benlloglu et al., 2005). In Syria, yield of faba bean (Vicia faba), lentil (Lens culinaris), and pea (Pisum satioum) increased by $331 \%, 441 \%$, and $92 \%$, respectively, after managing crenate broomrape (Orobanche crenata) using solarization (Linke et al., 1991). Solarization reduced weed incidence up to $99 \%$ in some corn (Zea mays) cultivars (Ahmad et al., 1996).

Previous research comparing various thicknesses ( 25 vs. $100 \mu \mathrm{m}$, 50 vs. $100 \mu \mathrm{m}$, and 75 vs. $150 \mu \mathrm{m}$ ) of plastic films found that thin plastic films were more effective for trapping solar radiation, thereby leading to increased soil heating (McGovern

\begin{tabular}{llll}
\hline $\begin{array}{l}\text { Units } \\
\text { To convert U.S. to SI, } \\
\text { multiply by }\end{array}$ & U.S. unit & SI unit & $\begin{array}{l}\text { To convert SI to U.S., } \\
\text { multiply by }\end{array}$ \\
\hline 0.3048 & $\mathrm{ft}$ & $\mathrm{m}$ & 3.2808 \\
0.0929 & $\mathrm{ft}^{2}$ & $\mathrm{~m}^{2}$ & 10.7639 \\
2.54 & inch(es) & $\mathrm{cm}$ & 0.3937 \\
25.4 & inch $(\mathrm{es})$ & $\mathrm{mm}$ & 0.0394 \\
25.4 & $\mathrm{mil}$ & $\mu \mathrm{m}$ & 0.0394 \\
$\left({ }^{\circ} \mathrm{F}-32\right) \div 1.8$ & ${ }^{\circ} \mathrm{F}$ & ${ }^{\circ} \mathrm{C}$ & $\left(1.8 \times{ }^{\circ} \mathrm{C}\right)+32$
\end{tabular}


and McSorley, 1997). Transparent mulches were found to be more effective than opaque mulches for pathogen suppression (McGovern and McSorley, 1997). Several recent solarization studies in Florida were conducted using ISO plastic film (ISO Poly Films, Gray Court, SC) (McGovern et al., 2004; Saha et al., 2007; Wang et al., 2006). The objective of the present study was to evaluate soil solarization by comparing plastic films from different manufacturers in terms of their durability and their effectiveness in suppressing weeds.

\section{Materials and methods}

Field experiments were conducted in the summer of 2007 and 2008 at the University of Florida Plant Science Research and Education Unit (lat. $29^{\circ} 24^{\prime} \mathrm{N}$, long. $82^{\circ} 9^{\prime} \mathrm{W}$ ), located near Citra, FL. The soil at the experimental site was Arredondo sand $(95 \%$ sand, $2 \%$ silt, and $3 \%$ clay) with $1.5 \%$ organic matter.

2007 EXPERIMENT. The experimental field was rototilled on 15 June to prepare soil and to improve heat conduction through the soil for solarization. On 9 July, soil was thoroughly irrigated because moist soils are better conductors of heat (Katan, 1981). Soil moisture content (measured gravimetrically) before bed formation averaged 9.6\%. On 10 July, beds were prepared that were $35 \mathrm{ft}$ long with 8 -ft centers. On 11 July, five treatments were applied manually by covering the beds with one of four types of transparent plastic films: ISO (1 mil thick, ultraviolet light-stabilized; ISO Poly Films, Gray Court, SC); VeriPack (2 mil thick; VeriPack, Framingham, MA); Poly Pak (2 mil thick; Poly Pak Plastics, Medford, $\mathrm{MN})$; Bromostop ${ }^{\circledR}$ (1.4 mil thick; Bruno Rimini, London); or a semiopaque white plastic film (2 mil thick; Rodeo Plastic Bag and Film, Mesquite, TX). These films were supplied in long rolls with width varying from 6 to $8.3 \mathrm{ft}$, and were cut into $40-\mathrm{ft}$ lengths. After covering the beds, the edges of the plastic were sealed by placing soil at the base and ends of each bed. Treatments were arranged in a randomized complete block design with five replications. Each plot was $35 \mathrm{ft}$ long with a raised bed top of 30 inches wide, 8 inches high, and the total bed surface area was $87.5 \mathrm{ft}^{2}$. Soil thermocouples attached to automatic data loggers (WatchDog ${ }^{\circledR}$; Spectrum Technologies, Plainfield, IL) were placed in the field on 11 July 2007. In a given bed, one soil temperature sensor was placed at $5 \mathrm{~cm}$ depth and one at $15 \mathrm{~cm}$ depth, with temperatures monitored hourly throughout the season. The experiment was ended after 10 weeks.

2008 EXPERIMENT. The experiment was repeated in the same field as the 2007 experiment. Experimental procedure was similar to that described for 2007, with minor changes as specified below. The experimental field was rototilled on 13 June, and beds were prepared on 24 June. Soil moisture content before bed formation averaged $6.4 \%$. Plastic films as well as soil thermocouples and data loggers were applied in the field on 25 June 2008. During the 2008 season, treatments remained the same except that ISO and VeriPack plastic films were no longer manufactured, therefore, a different plastic film was substituted: Polydak ${ }^{\circledR}(1.3$ mil thick, ultraviolet-stabilized, transparent film; Ginegar Plastics Products, Ginegar, Israel). Treatments were arranged in a randomized complete block design with five replications.

Data collection. Weed density was recorded for each weed present in plots from 3 to 12 weeks after treatment application. Weeds were counted as they broke through plastic [occasionally occurred with nutsedges (Cyperus spp.)] or more commonly as they emerged in open areas where the plastic had been torn. However, very small $(<0.4$ inch $)$ weed seedlings were classified simply as broadleaf, nutsedges, or grasses. In both years, as plastic films deteriorated, they typically split open perpendicular to the length of the bed, causing a break, or tear across the width of the bed. Durability was assessed every 2 weeks by counting
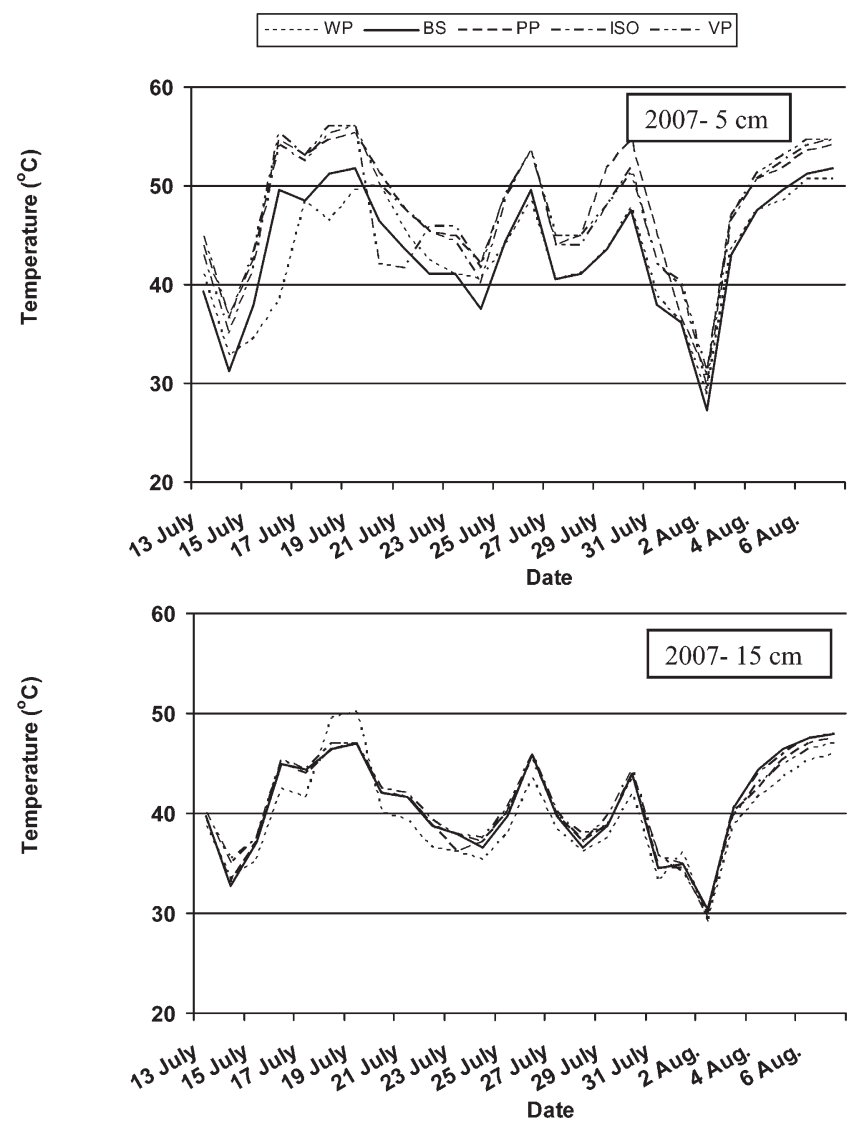

Fig. 1. Soil temperatures during solarization at 5 and $15 \mathrm{~cm}(2.0$ and 5.9 inches $)$ soil depth in 2007. WP $=$ white plastic $(2$ mil $), \mathrm{BS}=$ Bromostop $^{\circledR}(1.4$ mil; Bruno Rimini, London), PP = Poly Pak (2 mil; Poly Pak Plastics, Medford, MN), ISO = ISO Poly Films (1 mil; ISO Poly Films, Gray Court, SC); VP = VeriPack ( 2 mil; VeriPack, Framingham, MA); 1 mil $=25.4 \mu \mathrm{M},\left(1.8 \times{ }^{\circ} \mathrm{C}\right)+32={ }^{\circ} \mathrm{F}$. 
the number of breaks in the plastic films. Breaks were graded into four size classes: very small $=<0.75$ inch long; small $=<30$ inches long (less than the bed width); large $=30$ inches long (across the entire bed width), and extra large. Extra-large breaks extended across the entire bed width but opened up along the bed length as well. The area of each large break was calculated by multiplying the length and width of the break, and the total exposed area for each bed was determined by adding the areas of all extra-large breaks on each bed.

Data AnAlysis. Data were analyzed using a one-way analysis of variance (ANOVA) with SAS (version 9.1; SAS Institute, Cary, NC). When ANOVA showed a significant treatment

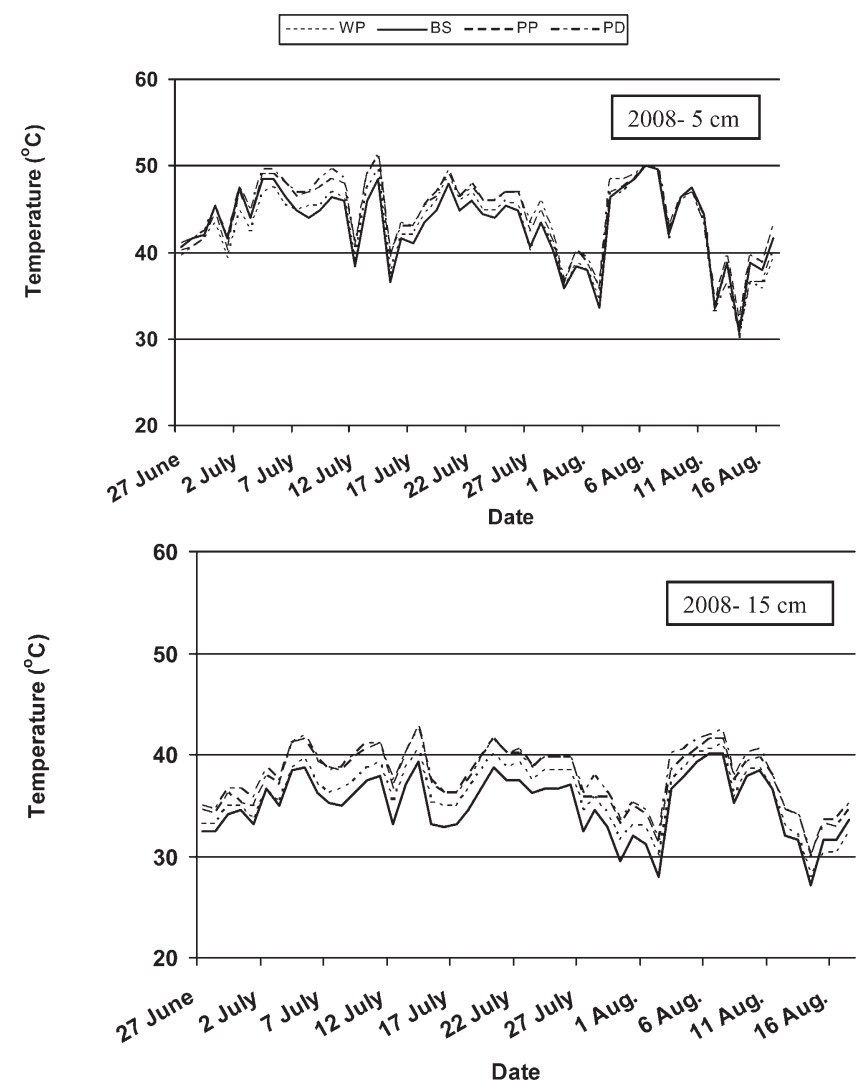

Fig. 2. Soil temperatures during solarization at 5 and $15 \mathrm{~cm}(2.0$ and 5.9 inches $)$ soil depth in 2008. WP $=$ white plastic $(2$ mil $), \mathrm{BS}=$ Bromostop $^{\circledR}$ (1.4 mil; Bruno Rimini, London), PP = Poly Pak (2 mil; Poly Pak Plastics, Medford, MN), PD = Polydak $^{\circledR}$ (1.3 mil; Ginegar Plastics Products, Ginegar, Israel $) ; 1 \mathrm{mil}=25.4 \mu \mathrm{M},\left(1.8 \times{ }^{\circ} \mathrm{C}\right)+32={ }^{\circ} \mathrm{F}$.

effect $(P \leq 0.05)$, treatment means were separated using the least significant difference test (LSD).

\section{Results and discussion}

Soil temperature was higher at the $5 \mathrm{~cm}$ soil depth than at $15 \mathrm{~cm}$ throughout both seasons (Figs. 1 and 2). During 2007, the highest temperatures recorded were $56{ }^{\circ} \mathrm{C}$ under ISO film ( $12 \mathrm{~d}$ at temperatures above $50{ }^{\circ} \mathrm{C}$ ) and $54.7^{\circ} \mathrm{C}$ under Poly Pak (11 d at temperatures above $50{ }^{\circ} \mathrm{C}$ ), at $5 \mathrm{~cm}$ soil depth (Fig. 1). In the 2008 season, soil temperatures near $50{ }^{\circ} \mathrm{C}$ at $5 \mathrm{~cm}$ soil depth were often recorded under fairly durable plastic films such as Polydak ${ }^{\circledR}$ and Poly Pak (Fig. 2)

Plastic durability. In 2007 , Bromostop ${ }^{\circledR}$ developed more small breaks than other clear plastic films in week 6 (Table 1). A greater number of large and extra-large breaks were found in Bromostop ${ }^{\circledR}$, VeriPack, and white plastic films as small-sized breaks progressed into large breaks over time. At the end of the experiment, a greater number of extra-large breaks were found in Bromostop ${ }^{\circledR}$, VeriPack, and white plastic films compared with other plastic films. No difference was found in exposed area among different plastic films initially, but as time progressed, Bromostop ${ }^{\circledR}$ developed more exposed area from breaks than white plastic film, while no difference was observed among ISO, VeriPack, and Poly Pak plastic films (Table 2). At the end of season, white plastic and Bromostop ${ }^{\circledR}$ plastic films had more exposed area than ISO, VeriPack, and Poly Pak films.

In 2008, early in the season, no difference was observed among treatments in number of small, large,

Table 1. Number of breaks over time in plastic films used for soil solarization and weed control in 2007.

\begin{tabular}{|c|c|c|c|c|c|c|c|c|c|c|}
\hline \multirow[b]{3}{*}{ Treatments $^{\mathrm{z}}$} & \multicolumn{10}{|c|}{ Time after treatment application (weeks) ${ }^{\mathrm{y}}$} \\
\hline & \multicolumn{4}{|c|}{ Small breaks (no. $)^{x}$} & \multicolumn{3}{|c|}{ Large breaks (no.) ${ }^{\mathrm{x}}$} & \multicolumn{3}{|c|}{ Extra large breaks (no.) ${ }^{x}$} \\
\hline & 5 & 6 & 7 & 8 & 6 & 7 & 8 & 6 & 7 & 8 \\
\hline Bromostop $^{\circledR}$ & $0.6 \mathrm{a}$ & $13.2 \mathrm{a}$ & $17.0 \mathrm{a}$ & $14.8 \mathrm{bc}$ & $2.0 \mathrm{ab}$ & $1.8 \mathrm{~b}$ & $0.6 \mathrm{~b}$ & $1.2 \mathrm{a}$ & $3.6 \mathrm{a}$ & $2.0 \mathrm{a}$ \\
\hline VeriPack & $0.4 \mathrm{a}$ & $0.6 \mathrm{~b}$ & $13.8 \mathrm{a}$ & $31.0 \mathrm{ab}$ & $0.2 \mathrm{ab}$ & $3.8 \mathrm{a}$ & $4.6 \mathrm{a}$ & $0.0 \mathrm{~b}$ & $0.0 \mathrm{~b}$ & $2.4 \mathrm{a}$ \\
\hline Poly Pak & $0.0 \mathrm{a}$ & $0.0 \mathrm{~b}$ & $0.0 \mathrm{~b}$ & $7.6 \mathrm{bc}$ & $0.0 \mathrm{~b}$ & $0.0 \mathrm{c}$ & $0.6 \mathrm{~b}$ & $0.0 \mathrm{~b}$ & $0.4 \mathrm{~b}$ & $0.2 \mathrm{~b}$ \\
\hline
\end{tabular}

${ }^{2}$ ISO film (1 mil; ISO Poly Films, Gray Court, SC), Bromostop ${ }^{\circledR}$ (1.4 mil; Bruno Rimini, London), VeriPack (2 mil; VeriPack, Framingham, MA), Poly Pak (2 mil; Poly Pak Plastics, Medford, MN), white plastic (2 mil); 1 mil $=25.4 \mu \mathrm{M}$.

Number of weeks after treatment applied in field.

x mall breaks were $<30$ inches $(76.2 \mathrm{~cm})$, less than the bed width; large breaks were 30 inches, across the entire bed width; extra large breaks extended across the entire bed width but opened up along the bed length as well.

${ }^{w}$ Mean values within the same column followed by same letter are not significantly different according to least significant difference test at $P \leq 0.05$. Number of breaks present in given week. Number can increase from week to week if more breaks occur. Number can decrease if smaller breaks expand in size and, therefore, become larger breaks. 
Table 2. Cumulative exposed area on beds from extra-large breaks (i.e., breaks that extended across the entire bed width but opened up along the bed length as well) over time in plastic films used for soil solarization and weed control in 2007.

\begin{tabular}{|c|c|c|c|}
\hline \multirow[b]{3}{*}{ Treatments ${ }^{\mathrm{z}}$} & \multicolumn{3}{|c|}{ Time after treatment application (weeks) ${ }^{\mathrm{y}}$} \\
\hline & 6 & 7 & 8 \\
\hline & \multicolumn{3}{|c|}{ Cumulative exposed area $\left(\mathrm{ft}^{2}\right)^{\mathrm{x}}$} \\
\hline ISO film & $0.00 \mathrm{a}^{\mathrm{w}}$ & $0.00 \mathrm{c}$ & $0.00 \mathrm{~b}$ \\
\hline Bromostop $^{(}$ & $2.04 \mathrm{a}$ & $35.29 \mathrm{a}$ & $67.47 \mathrm{a}$ \\
\hline VeriPack & $0.00 \mathrm{a}$ & $0.00 \mathrm{c}$ & $10.11 \mathrm{~b}$ \\
\hline Poly Pak & $0.00 \mathrm{a}$ & $0.11 \mathrm{c}$ & $3.34 \mathrm{~b}$ \\
\hline White plastic & $3.55 \mathrm{a}$ & $14.85 \mathrm{~b}$ & $56.92 \mathrm{a}$ \\
\hline
\end{tabular}

${ }^{2}$ ISO film (1 mil; ISO Poly Films, Gray Court, SC), Bromostop ${ }^{\circledR}$ ( 1.4 mil; Bruno Rimini, London), VeriPack (2 mil; VeriPack, Framingham, MA), Poly Pak (2 mil; Poly Pak Plastics, Medford, MN), white plastic (2 mil); 1 mil = $25.4 \mu \mathrm{m}$.

${ }^{y}$ Number of weeks after treatment applied in field

${ }^{x} 1 \mathrm{ft}^{2}=0.0929 \mathrm{~m}^{2}$; total bed area was $87.50 \mathrm{ft}^{2}$

"Mean values within the same column followed by same letter are not significantly different according to least significant difference test at $P \leq 0.05$.

and extra-large breaks, but as the season progressed, white plastic and Bromostop $^{\circledR}$ plastic films showed more breaks in comparison with Poly Pak and Polydak ${ }^{\circledR}$ films. The thin Polydak ${ }^{\circledR}$ plastic film developed a number of very small $(<0.75$ inch $)$ breaks due to large birds [sandhill crane (Grus canadensis)] walking on the film, but these did not develop into large breaks (Table 3). These very small breaks were observed in
2008 (mainly on Polydak ${ }^{\circledR}$ film), but not in 2007. The numbers of extralarge breaks increased toward the end of season because small and large breaks were torn further and led to extra-large breaks (Table 4). Exposed area from extra-large breaks was calculated on four different sampling dates. No exposed areas were found in Polydak ${ }^{\circledR}$ plastic film throughout the experiment and it remained intact in the field for 7 months. Ten weeks after the treatments were applied in the field, all of the Bromostop ${ }^{\circledR}$ and white plastic films were destroyed, and the total exposed area was the same as that of the bed surface $(87.50$ $\left.\mathrm{ft}^{2}\right)$. Poly Pak had 75\% less exposed area $\left(21.19 \mathrm{ft}^{2}\right)$ at 10 weeks compared with white plastic and Bromostop ${ }^{\circledR}$ films by the end of experiment (Table 5). Poly Pak and Polydak ${ }^{\circledR}$ plastic films were more durable when exposed to sunlight compared with white plastic and Bromostop ${ }^{\circledR}$ plastic films.

WEED POPULATION DENSITIES. In 2007 , the density of purple nutsedge was greatest in raised beds covered with white plastic film on all sampling dates (Table 6), which may be due to lower penetration of solar radiation through white plastic film. On 20 Sept., cudweed (Gnaphalium spp.), hairy indigo (Indigofera hirsuta), total grasses, and total broadleaf weeds were generally found to be significantly less under Poly Pak, VeriPack, and ISO plastic films than with white plastic and Bromostop $^{\circledR}$ plastic films (Table 7). Bromostop $^{\circledR}$ plastic film was not persistent under prolonged sunlight and was more prone to tearing, which led to the emergence of weeds from open

Table 3. Number of very small and small breaks over time in plastic films used for soil solarization and weed control in 2008.

\begin{tabular}{|c|c|c|c|c|c|c|c|c|c|c|c|}
\hline \multirow[b]{3}{*}{ Treatments $^{\mathrm{z}}$} & \multicolumn{11}{|c|}{ Time after treatment application (weeks) ${ }^{\mathrm{y}}$} \\
\hline & \multicolumn{6}{|c|}{ Very small breaks (no.) ${ }^{x}$} & \multicolumn{5}{|c|}{ Small breaks (no.) ${ }^{\mathrm{x}}$} \\
\hline & 2 & 4 & 6 & 8 & 10 & 12 & 4 & 6 & 8 & 10 & 12 \\
\hline Bromostop $^{\circledR}$ & $0.0 \mathrm{~b}$ & $0.0 \mathrm{~b}$ & $0.0 \mathrm{~b}$ & $0.0 \mathrm{~b}$ & $0.0 \mathrm{~b}$ & $0.0 \mathrm{~b}$ & $0.8 \mathrm{a}$ & $15.0 \mathrm{a}$ & $13.6 \mathrm{~b}$ & $0.0 \mathrm{~b}$ & $0.0 \mathrm{~b}$ \\
\hline Poly Pak & $0.6 \mathrm{~b}$ & $0.8 \mathrm{~b}$ & $0.8 \mathrm{~b}$ & $1.0 \mathrm{~b}$ & $1.0 \mathrm{~b}$ & $1.0 \mathrm{~b}$ & $0.0 \mathrm{a}$ & $0.0 \mathrm{~b}$ & $3.2 \mathrm{~b}$ & $11.8 \mathrm{a}$ & $13.2 \mathrm{a}$ \\
\hline Polydak $^{\circledR}$ & $3.6 \mathrm{a}$ & $3.6 \mathrm{a}$ & $3.6 \mathrm{a}$ & $11.6 \mathrm{a}$ & $12.6 \mathrm{a}$ & $12.6 \mathrm{a}$ & $0.0 \mathrm{a}$ & $0.0 \mathrm{~b}$ & $0.4 \mathrm{~b}$ & $0.0 \mathrm{~b}$ & $0.0 \mathrm{~b}$ \\
\hline
\end{tabular}

Table 4. Number of large and extra-large breaks over time in plastic films used for soil solarization and weed control in 2008.

\begin{tabular}{|c|c|c|c|c|c|c|c|c|}
\hline \multirow[b]{3}{*}{ Treatments $^{\mathrm{z}}$} & \multicolumn{8}{|c|}{ Time after treatment application (weeks) } \\
\hline & \multicolumn{4}{|c|}{ Large breaks (no.) ${ }^{\mathrm{x}}$} & \multicolumn{4}{|c|}{ Extra-large breaks (no.) ${ }^{x}$} \\
\hline & 6 & 8 & 10 & 12 & 6 & 8 & 10 & 12 \\
\hline Bromostop $^{\circledR}$ & $3.0 \mathrm{a}$ & $0.0 \mathrm{a}$ & $0.0 \mathrm{~b}$ & $0.0 \mathrm{~b}$ & $0.8 \mathrm{a}$ & $2.8 \mathrm{a}$ & $1.0 \mathrm{~b}$ & $0.0 \mathrm{~b}$ \\
\hline Poly Pak & $0.0 \mathrm{~b}$ & $0.6 \mathrm{a}$ & $4.4 \mathrm{a}$ & $3.8 \mathrm{a}$ & $0.0 \mathrm{a}$ & $0.0 \mathrm{~b}$ & $2.6 \mathrm{a}$ & $4.4 \mathrm{a}$ \\
\hline Polydak $^{\circledR}$ & $0.0 \mathrm{~b}$ & $0.0 \mathrm{a}$ & $0.0 \mathrm{~b}$ & $0.0 \mathrm{~b}$ & $0.0 \mathrm{a}$ & $0.0 \mathrm{~b}$ & $0.0 \mathrm{~b}$ & $0.0 \mathrm{~b}$ \\
\hline
\end{tabular}

${ }^{2}$ White plastic (2 mil), Bromostop ${ }^{\circledR}$ (1.4 mil; Bruno Rimini, London), Poly Pak (2 mil; Poly Pak Plastics, Medford, MN), Polydak ${ }^{\circledR}$ (1.3 mil; Ginegar Plastics Products, Ginegar, Israel); $1 \mathrm{mil}=25.4 \mu \mathrm{M}$.

${ }^{y}$ Number of weeks after treatment applied in field.

'Large breaks were 30 inches $(76.2 \mathrm{~cm})$, across the entire bed width; extra-large breaks extended across the entire bed width but opened up along the bed length as well.

w Mean values within the same column followed by same letter are not significantly different according to least significant difference test at $P \leq 0.05$. Number of breaks present in given week. Number can increase from week to week if more breaks occur. Number can decrease if smaller breaks expand in size and, therefore, become larger breaks. 
Table 5. Cumulative exposed area on beds over time from extra-large breaks (i.e., breaks that extended across the entire bed width but opened up along the bed length as well) in plastic films used for soil solarization and weed control in 2008.

\begin{tabular}{|c|c|c|c|c|}
\hline \multirow[b]{3}{*}{ Treatments $^{\mathrm{z}}$} & \multicolumn{4}{|c|}{ Time after treatment application (weeks) ${ }^{y}$} \\
\hline & 6 & 8 & 10 & 12 \\
\hline & \multicolumn{4}{|c|}{ Cumulative exposed area $\left(\mathrm{ft}^{2}\right)^{\mathrm{x}}$} \\
\hline White plastic & $0.49 \mathrm{a}^{\mathrm{w}}$ & $59.82 \mathrm{a}$ & $87.50 \mathrm{a}$ & $87.50 \mathrm{a}$ \\
\hline Bromostop $^{\circledR}$ & $0.30 \mathrm{a}$ & $54.55 \mathrm{a}$ & $87.50 \mathrm{a}$ & $87.50 \mathrm{a}$ \\
\hline Poly Pak & $0.00 \mathrm{a}$ & $0.00 \mathrm{~b}$ & $6.99 \mathrm{~b}$ & $21.19 \mathrm{~b}$ \\
\hline Polydak $^{\circledR}$ & $0.00 \mathrm{a}$ & $0.00 \mathrm{~b}$ & $0.00 \mathrm{c}$ & $0.00 \mathrm{c}$ \\
\hline
\end{tabular}

${ }^{2}$ White plastic (2 mil), Bromostop ${ }^{\otimes}$ (1.4 mil; Bruno Rimini, London), Poly Pak (2 mil; Poly Pak Plastics, Medford, $\mathrm{MN})$, Polydak $^{\circledast}$ (1.3 mil; Ginegar Plastics Products, Ginegar, Israel); $1 \mathrm{mil}=25.4 \mu \mathrm{M}$.

${ }^{y}$ Number of weeks after treatment applied in field.

${ }^{\mathrm{x}} 1 \mathrm{ft}^{2}=0.0929 \mathrm{~m}^{2}$; total bed area $=87.50 \mathrm{ft}^{2}$.

"Mean values within the same column followed by same letter are not significantly different according to least significant difference test at $P \leq 0.05$.

Table 6. Cumulative density of purple nutsedge over time in response to plastic films in 2007.

\begin{tabular}{|c|c|c|c|c|c|}
\hline \multirow[b]{3}{*}{ Treatments $^{\mathrm{z}}$} & \multicolumn{5}{|c|}{ Time after treatment application (weeks) ${ }^{y}$} \\
\hline & 3 & 5 & 8 & 10 & 12 \\
\hline & \multicolumn{5}{|c|}{ Cumulative density (stems/bed) ${ }^{x}$} \\
\hline ISO film & $0.2 \mathrm{c}^{\mathrm{w}}$ & $0.4 \mathrm{~b}$ & $6.4 \mathrm{~b}$ & $23.0 \mathrm{c}$ & $64.0 \mathrm{bc}$ \\
\hline Bromostop $^{\circledR}$ & $5.0 \mathrm{ab}$ & $11.2 \mathrm{a}$ & $66.0 \mathrm{~b}$ & $142.6 \mathrm{ab}$ & $267.2 \mathrm{ab}$ \\
\hline VeriPack & $2.0 \mathrm{abc}$ & $1.4 \mathrm{~b}$ & $16.6 \mathrm{~b}$ & $57.6 \mathrm{bc}$ & $140.0 \mathrm{bc}$ \\
\hline Poly Pak & $0.4 \mathrm{bc}$ & $1.0 \mathrm{~b}$ & $8.4 \mathrm{~b}$ & $18.6 \mathrm{c}$ & $42.6 \mathrm{c}$ \\
\hline White plastic & $5.8 \mathrm{a}$ & $13.0 \mathrm{a}$ & $136.0 \mathrm{a}$ & $197.2 \mathrm{a}$ & $425.0 \mathrm{a}$ \\
\hline
\end{tabular}

${ }^{z}$ ISO film (1 mil; ISO Poly Films, Gray Court, SC), Bromostop ${ }^{\circledR}$ (1.4 mil; Bruno Rimini, London), VeriPack (2 mil; VeriPack, Framingham, MA), Poly Pak (2 mil; Poly Pak Plastics, Medford, MN), white plastic $(2 \mathrm{mil}) ; 1 \mathrm{mil}=$ $25.4 \mu \mathrm{M}$.

${ }^{y}$ Number of weeks after treatment applied in field.

${ }^{\mathrm{x}} 1 \mathrm{stem} / 87.50-\mathrm{ft}^{2}\left(8.129 \mathrm{~m}^{2}\right)$ bed $=0.1230 \mathrm{stem} / \mathrm{m}^{2}$.

${ }^{\mathrm{w}}$ Mean values within the same column followed by same letter are not significantly different according to least significant difference test at $P \leq 0.05$.

Table 7. Density of common weeds at 10 weeks after treatment with plastic films in 2007.

\begin{tabular}{llcccr}
\hline & Purslane & Cudweed & Hairy indigo & Grasses $^{\mathrm{y}}$ & Broadleaf $^{\text {Treatments }}$ \\
\cline { 2 - 6 } & \multicolumn{5}{c}{${\text { (weeds } / \mathrm{bed})^{\mathrm{x}}}^{\mathrm{y}}$} \\
\hline ISO film & $0.0 \mathrm{a} \mathrm{a}^{\mathrm{w}}$ & $0.0 \mathrm{~b}$ & $0.0 \mathrm{~b}$ & $0.0 \mathrm{~b}$ & $0.0 \mathrm{~b}$ \\
Bromostop $^{\circledR}$ & $1.2 \mathrm{a}$ & $1.8 \mathrm{ab}$ & $2.0 \mathrm{a}$ & $9.8 \mathrm{ab}$ & $8.8 \mathrm{a}$ \\
VeriPack & $0.0 \mathrm{a}$ & $0.4 \mathrm{~b}$ & $0.0 \mathrm{~b}$ & $1.8 \mathrm{~b}$ & $0.4 \mathrm{~b}$ \\
Poly Pak & $0.0 \mathrm{a}$ & $0.0 \mathrm{~b}$ & $0.6 \mathrm{ab}$ & $1.4 \mathrm{~b}$ & $0.0 \mathrm{~b}$ \\
White plastic & $3.4 \mathrm{a}$ & $5.2 \mathrm{a}$ & $1.4 \mathrm{ab}$ & $27.6 \mathrm{a}$ & $11.2 \mathrm{a}$ \\
\hline
\end{tabular}

${ }^{\mathrm{z}}$ ISO film (1 mil; ISO Poly Films, Gray Court, SC), Bromostop ${ }^{\circledR}$ (1.4 mil; Bruno Rimini, London), VeriPack (2 mil; VeriPack, Framingham, MA), Poly Pak (2 mil; Poly Pak Plastics, Medford, MN), white plastic (2 mil); 1 mil = $25.4 \mu \mathrm{M}$.

y Predominantly crabgrass and bermudagrass.

${ }^{\mathrm{x}} \mathrm{l}$ weed $/ 87.50-\mathrm{ft}^{2}\left(8.129 \mathrm{~m}^{2}\right)$ bed $=0.1230$ weed $/ \mathrm{m}^{2}$

${ }^{\text {w}}$ Mean values within the same column followed by same letter are not significantly different according to least significant difference test at $P \leq 0.05$.

areas on raised beds. Purple nutsedge was the major weed present throughout the season. Generally, ISO and Poly Pak plastic films were found to be more effective for managing purple nutsedge compared with white plastic and Bromostop ${ }^{\circledR}$ films. The differential penetration of opaque and clear plastic mulches might be explained by a light-dependent morphological change from rhizome elongation to leaf expansion (Chase et al., 1998).
In 2008, purple nutsedge was present early in the season and density increased as the season progressed. Significantly greater density of purple nutsedge was found in Bromostop ${ }^{\circledR}$ and white plastic films than in Poly Pak and Polydak ${ }^{\circledR}$ plastic films. No difference among treatments was found in density of broadleaf weeds at the start of season, but at the end of season, broadleaf weed density was significantly greater in Bromostop ${ }^{\circledR}$ and white plastic compared with Poly Pak and Polydak ${ }^{\circledR}$ films (Table 8).

In previous studies, soil solarization controlled annual weeds better than perennial weeds because some perennial weeds resprout from deeply buried underground vegetative structures (Elmore et al., 1997). Among the perennials, the seeds of bermudagrass (Cynodon dactylon), johnsongrass (Sorghum halepense), and field bindweed (Convolvulus arvensis) were controlled, but purslane (Portulaca oleracea), crabgrass (Digitaria sanguinalis), and yellow nutsedge (Cyperus esculentus) were only partially managed by soil solarization. Destruction of weeds such as cogongrass (Imperata cylindrica), pigweed (Amaranthus spp.), purslane, foxtail (Setaria spp.), and crabgrass (Digitaria spp.) was visually observed after removal of plastic films used for a soil solarization study in highlands of the West Province of Cameroon (Daelemans, 1989).

In the current study, purple nutsedge was controlled using more durable plastic films such as Polydak ${ }^{\circledR}$, Poly Pak, and ISO compared with Bromostop ${ }^{\circledR}$ and white plastic films. Purple nutsedge was the dominant weed during 2007 and 2008, and although it is known to cause punctures and breaks in plastic films (Chase et al., 1998), it was controlled under several of the solarization films used in the current study. Much of the high nutsedge populations in the current study likely resulted from emergence in areas exposed due to breaks in the films. Many of the small breaks recorded during both years resulted from breakdown of the plastic films and did not contain nutsedge plants. Nutsedge populations increased greatly in these exposed areas as plants emerged. Some puncturing of plastic by nutsedge was observed, particularly with the white plastic. However, the white plastic was not very durable and it developed many additional breaks as the plastic deteriorated. The similar high populations of nutsedge later in the season under the semiopaque white plastic (more likely to be punctured by nutsedge) and the clear Bromostop ${ }^{\circledR}$ (less likely to be punctured due to solar heating) suggest that a similar mechanism led to nutsedge population buildup. In this case, that mechanism could be the breakdown of both plastic types. 
Table 8. Density of common weeds over time in response to plastic films in 2008.

\begin{tabular}{|c|c|c|c|c|c|c|c|c|}
\hline \multirow[b]{4}{*}{ Treatments $^{\mathrm{z}}$} & \multicolumn{8}{|c|}{ Time after treatment application (weeks) ${ }^{\mathrm{y}}$} \\
\hline & \multicolumn{5}{|c|}{ Nutsedges } & \multicolumn{3}{|c|}{ Broadleaf } \\
\hline & 2 & 4 & 6 & 8 & 10 & 6 & 8 & 10 \\
\hline & \multicolumn{8}{|c|}{$(\text { weeds/bed })^{x}$} \\
\hline White plastic & $10.6 \mathrm{ab}^{\mathrm{w}}$ & $12.8 \mathrm{ab}$ & $48.4 \mathrm{a}$ & $173.2 \mathrm{a}$ & $363.2 \mathrm{a}$ & $0.0 \mathrm{a}$ & $0.0 \mathrm{~b}$ & $3.0 \mathrm{ab}$ \\
\hline Bromostop $^{\circledR}$ & $16.8 \mathrm{a}$ & $21.2 \mathrm{a}$ & $59.6 \mathrm{a}$ & $211.0 \mathrm{a}$ & $380.4 \mathrm{a}$ & $0.2 \mathrm{a}$ & $0.6 \mathrm{a}$ & $4.4 \mathrm{a}$ \\
\hline Poly Pak & $0.2 \mathrm{c}$ & $2.6 \mathrm{~b}$ & $1.8 \mathrm{~b}$ & $3.6 \mathrm{~b}$ & $20.8 \mathrm{~b}$ & $0.0 \mathrm{a}$ & $0.0 \mathrm{~b}$ & $0.2 \mathrm{bc}$ \\
\hline Polydak $^{\circledR}$ & $5.6 \mathrm{bc}$ & $6.4 \mathrm{~b}$ & $12.4 \mathrm{~b}$ & $16.0 \mathrm{~b}$ & $19.4 \mathrm{~b}$ & $0.0 \mathrm{a}$ & $0.0 \mathrm{~b}$ & $0.0 \mathrm{c}$ \\
\hline
\end{tabular}

${ }^{2}$ White plastic (2 mil), Bromostop ${ }^{\otimes}$ (1.4 mil; Bruno Rimini, London); Poly Pak (2 mil; Poly Pak Plastics, Medford, $\mathrm{MN})$, Polydak ${ }^{\circledR}(1.3 \mathrm{mil}$; Ginegar Plastics Products, Ginegar, Israel); 1 mil $=25.4 \mu \mathrm{M}$.

${ }^{y}$ Number of weeks after treatment applied in field.

${ }^{x} 1$ weed $/ 87.50-\mathrm{ft}^{2}\left(8.129 \mathrm{~m}^{2}\right)$ bed $=0.1230$ weed $/ \mathrm{m}^{2}$.

"Mean values within the same column followed by same letter are not significantly different according to least significant difference test at $P \leq 0.05$.

Solarization times of 6 weeks or longer are needed for consistent weed management (McGovern and McSorley, 1997), and these were achieved by some of the plastics used here. However, if plastic breaks down prematurely, the temperatures in the exposed areas cool, and weeds such as nutsedge are better able to survive and emerge. Ultraviolet-stabilized films (Polydak ${ }^{\circledR}$ and ISO) were durable, while the durability of plastic films that were not ultraviolet stabilized was variable. Poly Pak and VeriPack were stable under field conditions, but Bromostop ${ }^{\circledR}$ and white plastic deteriorated rapidly and did not provide season-long control of nutsedges. Polydak ${ }^{\circledR}$ remained intact throughout the season, even though the film is very thin.

\section{Literature cited}

Ahmad, Y., A. Hameed, and M. Aslam. 1996. Effect of soil solarization on corn stalk rot. Plant Soil 179:17-24.

Benlloglu, S., O. Boz, A. Yildiz, G. Kaskavalci, and K. Benlioglu. 2005. Alternative soil solarization treatments for the control of soil-borne diseases and weeds of strawberry in the Western Anatolia of Turkey. J. Phytopathol. 153:423-430.

Chase, C.A. 2007. Soilborne plant pathogens and pest management with soil solarization. 12 Jan. 2009. <http://www. imok.ufl.edu/LIV/groups/cultural/ pests/solar.htm>.

Chase, C.A., T.R. Sinclair, D.G. Shilling, J.P. Gilreath, and S.J. Locascio. 1998. Light effects on rhizome morphogenesis in nutsedges (Cyperus spp.): Implications for control by soil solarization. Weed Sci. $46: 575-580$.
Chellemi, D.O. and J. Mirusso. 2006. Optimizing soil disinfection producers for fresh market tomato and pepper production. Plant Dis. 90:668-674.

Chellemi, D.O., S.M. Olson, D.J. Mitchell, I. Secker, and R. McSorley. 1997. Adaptation of soil solarization to the integrated management of soilborne pests of tomato under humid conditions. Phytopathology 87:250-258.

Chellemi, D.O., S.M. Olson, J.W. Scott, and D.J. Mitchell. 1993. Reduction of phytoparasitic nematodes on tomato by soil solarization and genotype. J. Nematol. 25(suppl.):800-805.

Culman, S.W., J.M. Duxbury, J.G. Lauren, and J.E. Thies. 2006. Microbial community response to soil solarization in Nepal's rice-wheat cropping system. Soil Biol. Biochem. 38:3359-3371.

Daelemans, A. 1989. Soil solarization in West-Cameroon: Effect on weed control, some chemical properties and pathogens of the soil. Acta Hort. 255:169-175.

Elmore, C.L., J.J. Stapleton, C.E. Bell, and J.E. DeVay. 1997. Soil solarization a nonpesticidal method for controlling diseases, nematodes and weeds. 14 Jan. 2009. <http://www.vric.ucdavis.edu/veginfo/ topics/soils/soilsolarization.pdf>.

Heald, C.M. and A.F. Robinson. 1987. Effects of soil solarization on Rotylenchulus reniformis in the lower Rio Grande Valley of Texas. J. Nematol. 19:93-103.

Horowitz, M., Y. Regev, and G. Herzlinger. 1983. Solarization for weed control. Weed Sci. 31:170-179.

Katan, J. 1981. Solar heating (solarization) of soil for control of soilborne pests. Annu. Rev. Phytopathol. 19:211-236.

Katan, J. 1987. Soil solarization, p. 77105. In: I. Chet (ed.). Innovative approaches to plant disease control. Wiley, New York.
Linke, K.H., M.C. Saxena, J. Sauerborn, and H. Masri. 1991. Effect of soil solarization on the yield of food legumes and on pest control, p. 139-154. In: J.E. DeVay, J.J. Stapleton, and C.L. Elmore (eds.). Soil solarization. FAO Plant Production and Protection Paper 109. Food and Agriculture Organization of the United Nations, Rome.

McGovern, R.J. and R. McSorley. 1997. Physical methods of soil sterilization for disease management including soil solarization, p. 283-313. In: N.A. Rechcigl and J.E. Rechcigl (eds.). Environmentally safe approaches to crop disease control. CRC, Lewis Publishers, Boca Raton, FL.

McGovern, R.J., R. McSorley, and K.-H. Wang. 2004. Optimizing bed orientation and number of plastic layers for soil solarization in Florida. Soil Crop Sci. Soc. Florida Proc. 36:133-139.

McGovern, R.J., R. McSorley, and M.L. Bell. 2002. Reduction of landscape pathogens in Florida by soil solarization. Plant Dis. 86:1388-1395.

McSorley, R. and J.L. Parrado. 1986. Application of soil solarization to Rockdale soils in a subtropical environment. Nematropica 16:125-140.

Saha, S.K., K.-H. Wang, R. McSorley, R.J. McGovern, and N. Kokalis-Burelle. 2007. Effect of solarization and cowpea cover crop on plant-parasitic nematodes, pepper yields, and weeds. Nematropica 37:51-63.

Scannavini, M., L. Antoniacci, and A. Brunelli. 1993. Experiments in soil solarization in Emilia-Romagna for the control of lettuce drop. Informatore Fitopatologico 43:30-35.

Stapleton, J.J. 2000. Soil solarization in various agricultural production systems. Crop Prot. 19:837-841.

Stapleton, J.J. and C.M. Heald. 1991. Management of phytopathogenic nematodes by soil solarization, p. 51-59. In: J. Katan and J.E. DeVay (eds.). Soil solarization. CRC Press, Boca Raton, FL.

Stapleton, J.J. and J.E. DeVay. 1983. Response of phytoparasitic and free-living nematodes to soil solarization and 1, 3dichloropropene in California. Phytopathology 73:1429-1436.

Wang, K.-H., R. McSorley, and N. KokalisBurelle. 2006. Effects of cover cropping, solarization, and soil fumigation on nematode communities. Plant Soil 286:229243. 